\title{
In-vitro contractility of rat seminiferous tubules in response to prostaglandins, cyclic GMP, testosterone and $2,4^{\prime}$-dibromoacetophenone*
}

\author{
C. H. Farr and L. C. Ellis \\ Department of Biology, Utah State University, Logan, Utah 84322, U.S.A.
}

\begin{abstract}
Summary. The effects of prostaglandin (PG) F-2 $\alpha$ and E-2, cyclic GMP, testosterone and 2,4'-dibromoacetophenone (DBA) on rat seminiferous tubules in vitro were ascertained by measuring contractile frequency, size of contractions and tone (tubular diameter). PGF-2 $\alpha\left(10^{-9}-10^{-5} \mathrm{M}\right)$ increased frequency and tone but not magnitude of contraction. Contraction frequency and tone were decreased by PGE-2 $\left(10^{-9}-10^{-5} \mathrm{M}\right)$ but the size of contractions was again unaffected. Cyclic GMP $\left(10^{-10}-10^{-6} \mathrm{M}\right)$ increased the frequency of contractions and tone and decreased size of contractions. Testosterone decreased the frequency and size of contractions and increased tone at concentrations of $10^{-9}$ to $10^{-7}$ but higher concentrations $\left(10^{-6} \mathrm{M}\right)$ reversed these changes. DBA $\left(10^{-7}-10^{-3} \mathrm{M}\right)$ greatly decreased the frequency and size of contractions and tone and spontaneous contractions were abolished at $10^{-3}$ M. Our data strongly suggest that PGs, cyclic nucleotides and testosterone are all important in vivo in modulating contractility of seminiferous tubules and as such would participate in sperm transport from the testes.
\end{abstract}

\section{Introduction}

Many hypotheses have been proposed to explain how spermatozoa are transported from the seminiferous tubules into the epididymis. Several investigators (Oslund, 1926; Harrison, 1953; Smith, 1962; Hargrove, MacIndoe \& Ellis, 1977) have suggested that fluid secretion and fluid flow in the seminiferous tubules all are responsible for sperm transport. Zawisch-Ossenitz (1933) postulated that movement of cilia in the efferent ducts was a factor in sperm transport, but this was refuted by Leeson (1963) who found very few cilia in the efferent ducts of the male rat. Wincet (1977) calculated that the cilia of the rat ductus efferentes could only propel approximately $3.7 \times 10^{-5} \mathrm{ml}$ fluid per day. Another possible explanation for the transport of mature spermatozoa suspended in testicular fluid is testicular capsular contractions (Davis \& Langford, 1970; Seeley, Hargrove, Johnson \& Ellis, 1972; Hargrove, Seeley \& Ellis, 1973; Leeson \& Cookson, 1974; Firlit, King \& Davis, 1975) although in rodents, at least, capsular contractions are not rhythmic (Ellis, Buhrley \& Hargrove, 1978). Contractions of the seminiferous tubules have also been suggested. The peristaltic movement of individual seminiferous tubules were originally attributed to contraction and relaxation of Sertoli cells (Roosen-Runge, 1951). More recent investigations, however, show that the 'boundary tissue' of the seminiferous tubules contains myoid cells which resemble smooth muscle cells (Clermont, 1958; Ross \& Long, 1966; Ross, 1967). The boundary tissue of most mammalian seminiferous tubules consists of cellular and noncellular components arrayed in four layers (Lacy, 1967). From micropuncture studies, Suvanto \& Kormano (1970) concluded that tubular contractions do aid transport of spermatozoa and tubular fluid to the rete testis by promoting fluid transport.

* Reprint requests to Professor L. C. Ellis. 
Prostaglandins (PGs) can affect tubular contractions (Buhrley \& Ellis, 1975; Tso \& Lacy, 1975) and are synthesized and metabolized in the testes (Ellis, 1972; Carpenter, 1974). Testosterone, at physiological concentrations, stimulates contractions of myoid cells in seminiferous tubules (Hovatta, 1972; Urry, Asay \& Cockett, 1977).

This investigation was undertaken to evaluate the effects of various substances on the contractility of rat seminiferous tubules in vitro.

\section{Materials and Methods}

Testes were removed from 350-500 g rats (locally bred from Holtzman Laboratory stock maintained in our small-animal facility) after cervical dislocation or ether anaesthesia. After removal of the tunica albuginea, the testes were placed in a muscle warmer (an all-glass waterjacketed container) which contained Tyrode's solution ( $1 \mathrm{~g} \mathrm{NaHCO}, 8 \mathrm{~g} \mathrm{NaCl}, 0.264 \mathrm{~g}$ $\mathrm{CaCl}_{2} \cdot 2 \mathrm{H}_{2} \mathrm{O}, 0.1 \mathrm{~g} \mathrm{MgCl}_{2}, 0.05 \mathrm{~g} \mathrm{Na}_{2} \mathrm{HPO}_{4}, 1 \mathrm{~g}$ glucose, all in 1 litre; the $\mathrm{NaHCO}_{3}$ was completely dissolved before adding $\mathrm{CaCl}_{2}$ ) maintained at normal scrotal temperature $\left(33^{\circ} \mathrm{C}\right)$ (Kormano, 1967; Collins \& Lacy, 1969). The Tyrode's solution in the muscle warmer was continuously oxygenated with filtered, compressed air.

Seminiferous tubules were obtained by placing a decapsulated testis in a Petri dish containing warmed Tyrode's solution under a dissecting microscope. Lengths $(1 \mathrm{~cm})$ of individual openended tubules were teased from the interstitial tissue and were placed in several drops of the appropriate test solutions on a microscope slide supported in a water-jacketed Plexiglass chamber attached to a microscope stage. The chamber was fitted with a cover which allowed the microscope objective to penetrate, thus maintaining the integrity of the internal environment. Temperature-sensitive crystals (Edmund Scientific Co., U.S.A.), that changed colour with changes in temperature, were attached to the ends of a microscope slide placed below the slide on which the seminiferous tubular segments were placed. These crystals monitored the internal temperature of the chamber which was maintained at $33^{\circ} \mathrm{C}$. Deionized water was placed in the bottom of the chamber under the microscope slides to maintain a high internal humidity and minimize changes in composition of the incubation medium.

The individual tubules were examined in transmitted light at a magnification of $\times 215$ and with a calibrated ocular micrometer to measure (1) the diameter of the tubule before $\left(d_{2}\right)$ and after treatment $\left(d_{1}\right)$ as a measure of change in tone, and (2) the size of the contractions $\left(d_{3}\right.$ see Text-fig. 1). The size of the contraction and tubule diameter was measured to the nearest $2 \mu \mathrm{m}$. Each treatment was replicated 8 times with 1 tubule from 8 different animals. Frequencies of contractions were determined by observing a specific site on the tubule for a 1 -min period. The concentrations of the various test solutions were $10^{-5}-10^{-9}$ M-PGE-2 and PGF-2 $\alpha$ (tromethamine salt, Upjohn Co., Kalamazoo, U.S.A.), $10^{-4}-10^{-8}$ M-cyclic GMP (cGMP), (Sigma Chemical Co., St Louis, U.S.A.), $10^{-6}-10^{-10} \mathrm{M}$-testosterone (Sigma Chemical Co.) and $10^{-3}-10^{-7}$ M-2,4' -dibromoacetophenone (Sigma Chemical Co.), a phospholipase $\mathrm{A}_{2}$ and PG synthesis inhibitor. All solutions were serially diluted in Tyrode's solution. The testosterone and $2,4^{\prime}$-dibromoacetophenone were first dissolved in several drops of ethanol.

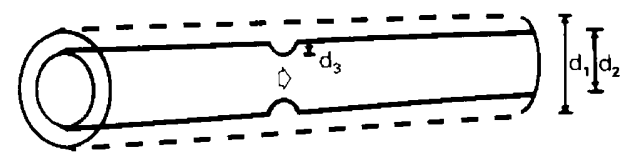

Text-fig. 1. Diagram of a seminiferous tubule showing how the measurements of size of contractions and tone were measured before ( - ) and after (----) treatment. Once the contraction was initiated it usually proceeded unidirectionally away from the site of origin (open arrow). Tone was reflected in a change of diameter of the tubule $\left(d_{1}-d_{2}\right)$, i.e. a greater difference indicated reduced tone. The size of an individual contraction was represented by $d_{3}$. 
Statistical analytical techniques were adapted from those described by Neter \& Wasserman (1974). The variances of the treatment means were tested for homogeneity by Bartlett's test. A single-factor analysis of variance was employed to analyse the effects of the various compounds and differences among treatment means were calculated by Tukey's multiple comparison test.

\section{Results}

Rat seminiferous tubules in Tyrode's solution had a normal external diameter of about $330 \mu \mathrm{m}$. Foci of contractions occurred about every $10 \mathrm{sec}$ along the tubules with a magnitude of 4-6 $\mu \mathrm{m}$. The effects of the various test substances in the fluid bathing the tubule segments are shown in Tables 1-4. The higher doses of PGF-2 $\alpha$ and PGE-2 affected the frequency of contractions and tone of the tubule (Table 1) but the magnitude of the contractions was unaffected. Cyclic GMP affected all 3 factors in a dose-dependent manner (Table 2). Testosterone had a biphasic effect, there being a reduced frequency and magnitude of contractions and increased tubule diameter (i.e. decreased tone) at $10^{-9}-10^{-7} \mathrm{M}$ concentrations (Table 3). The response to $2,4^{\prime}$-dibromoacetophenone was the reverse of that to PGF-2 $\alpha$ and cGMP except for size of contractions (Table 4). Complete inhibition of contractions occurred with a dose of $10^{-3} \mathrm{M}$.

Table 1. Some effects (mean \pm s.e.m., 8 tubules at each concentration) of PGE-2 and PGF-2 $\alpha$ on contractility of rat seminiferous tubules in vitro

\begin{tabular}{|c|c|c|c|c|c|c|}
\hline & \multirow[b]{2}{*}{ Controls } & \multicolumn{5}{|c|}{ PG concentration (M) } \\
\hline & & $10^{-5}$ & $10^{-6}$ & $10^{-7}$ & $10^{-8}$ & $10^{-9}$ \\
\hline \multicolumn{7}{|l|}{$\begin{array}{c}\text { Contraction } \\
\text { frequency } \\
\text { (no./min) }\end{array}$} \\
\hline $\begin{array}{l}\text { PGF-2 } \alpha \\
\text { PGE-2 }\end{array}$ & $\begin{array}{l}6 \cdot 12 \pm 0 \cdot 18 \\
6 \cdot 10 \pm 0.25\end{array}$ & $\begin{array}{l}8.17 \pm 0.32 \dagger \\
4.92 \pm 0.10\end{array}$ & $\begin{array}{l}7 \cdot 10 \pm 0.42 \\
6.12 \pm 0.57\end{array}$ & $\begin{array}{l}6.33 \pm 0.31 \\
6.21 \pm 0.30\end{array}$ & $\begin{array}{l}6.17 \pm 0.23 \\
5.96 \pm 0.29\end{array}$ & $\begin{array}{l}6.16 \pm 0.30 \\
6.04 \pm 0.42\end{array}$ \\
\hline \multicolumn{7}{|c|}{$\begin{array}{l}\text { Diam. of tubules } \\
(\mu \mathrm{m})\end{array}$} \\
\hline $\begin{array}{l}\text { PGF-2 } \alpha \\
\text { PGE-2 }\end{array}$ & $\begin{array}{l}332 \cdot 0 \pm 8 \cdot 3 \\
319 \cdot 8 \pm 5 \cdot 1\end{array}$ & $\begin{array}{l}280.1 \pm 4.9 \dagger \\
345.8 \pm 3.3^{*}\end{array}$ & $\begin{array}{l}285.6 \pm 7.7 \dagger \\
328.6 \pm 6.9\end{array}$ & $\begin{array}{l}304 \cdot 0 \pm 10 \cdot 4 \\
322 \cdot 3 \pm 6 \cdot 2\end{array}$ & $\begin{array}{l}310.4 \pm 10.4 \\
317.9 \pm 6.4\end{array}$ & $\begin{array}{l}317 \cdot 0 \pm 6 \cdot 6 \\
318.8 \pm 6 \cdot 3\end{array}$ \\
\hline \multicolumn{7}{|c|}{$\begin{array}{l}\text { Size of contraction } \\
(\mu \mathrm{m})\end{array}$} \\
\hline $\begin{array}{l}\text { PGF-2 } \alpha \\
\text { PGE-2 }\end{array}$ & $\begin{array}{l}5.40 \pm 0.20 \\
6.06 \pm 0.27\end{array}$ & $\begin{array}{l}4.86 \pm 0.21 \\
5.15 \pm 0.23\end{array}$ & $\begin{array}{l}4.90 \pm 0.29 \\
5.29 \pm 0.29\end{array}$ & $\begin{array}{l}5.18 \pm 0.29 \\
5.34 \pm 0.22\end{array}$ & $\begin{array}{l}5.28 \pm 0.27 \\
5.59 \pm 0.29\end{array}$ & $\begin{array}{l}5.23 \pm 0.24 \\
5.68 \pm 0.37\end{array}$ \\
\hline
\end{tabular}

Significantly different from control value: ${ }^{*} P<0.05 ; \dagger P<0.01$.

Table 2. Some effects (mean \pm s.e.m., 8 tubules at each concentration) of cGMP on rat seminiferous tubules in vitro

\begin{tabular}{lcccccc}
\hline & & \multicolumn{5}{c}{ cGMP concentration (M) } \\
\cline { 2 - 6 } & Controls & $10^{-6}$ & $10^{-7}$ & $10^{-8}$ & $10^{-9}$ & $10^{-10}$ \\
\hline $\begin{array}{c}\text { Contraction fre- } \\
\text { quency (no./min) }\end{array}$ & $6.08 \pm 0.31$ & $8.91 \pm 0.18 \ddagger$ & $8.38 \pm 0.28 \ddagger$ & $7.29 \pm 0.28$ & $6.50 \pm 0.40$ & $6.25 \pm 0.31$ \\
$\begin{array}{c}\text { Diam. of tubules } \\
(\mu \mathrm{m})\end{array}$ & $322.2 \pm 6.5$ & $263.8 \pm 4.7 \ddagger$ & $276.7 \pm 4.9 \ddagger$ & $285.1 \pm 4.8 \dagger$ & $299.7 \pm 4.3^{*}$ & $309.8 \pm 5.8$ \\
$\begin{array}{c}\text { Size of contraction } \\
(\mu \mathrm{m})\end{array}$ & $5.85 \pm 0.22$ & $4.55 \pm 0.30^{-1} \dagger$ & $4.89 \pm 0.19^{*}$ & $4.96 \pm 0.19^{*}$ & $5.51 \pm 0.11$ & $5.60 \pm 0.16$ \\
\hline
\end{tabular}

Significantly different from control values: ${ }^{*} P<0.05 ; \uparrow P<0.01 ; \ddagger P<0.001$. 
Table 3. Some effects (mean \pm s.e.m., 8 tubules at each concentration) of testosterone on rat seminiferous tubules in vitro

\begin{tabular}{lcccccc}
\hline & & \multicolumn{5}{c}{ Testosterone concentration (M) } \\
\cline { 3 - 7 } & Control & $10^{-6}$ & $10^{-7}$ & $10^{-8}$ & $10^{-9}$ & $10^{-10}$ \\
\hline $\begin{array}{c}\text { Contraction } \\
\text { frequency } \\
(\text { no. } / \text { min) }\end{array}$ & $6.29 \pm 0.33$ & $5.83 \pm 0.20$ & $5.29 \pm 0.20^{*}$ & $3.87 \pm 0.28 \dagger$ & $4.33 \pm 0.24 \dagger$ & $5.75 \pm 0.14$ \\
$\begin{array}{c}\text { Diam. of tubules } \\
(\mu \mathrm{m})\end{array}$ & $321.2 \pm 3.4$ & $330.1 \pm 5.3$ & $328.4 \pm 5.2$ & $355.5 \pm 4.3$ & $337.7 \pm 3.3 \dagger$ & $320.1 \pm 4.9$ \\
$\begin{array}{c}\text { Size of contraction } \\
(\mu \mathrm{m})\end{array}$ & $6.02 \pm 0.21$ & $5.96 \pm 0.12$ & $5.16 \pm 0.22^{*}$ & $3.98 \pm 0.23 \pm$ & $5.05 \pm 0.12 \dagger$ & $5.54 \pm 0.13$ \\
\hline
\end{tabular}

Significantly different from control value: ${ }^{*} P<0.05 ; \uparrow P<0.01 ; \ddagger P<0.001$.

Table 4. Some effects (mean \pm s.e.m., 8 tubules at each observation) of DBA on rat seminiferous tubules in vitro

\begin{tabular}{|c|c|c|c|c|c|c|}
\hline & \multirow[b]{2}{*}{ Control } & \multicolumn{5}{|c|}{ DBA concentration $(M)$} \\
\hline & & $10^{-3}$ & $10^{-4}$ & $10^{-5}$ & $10^{-6}$ & $10^{-7}$ \\
\hline $\begin{array}{l}\text { Contraction } \\
\text { frequency } \\
\text { (no./min) }\end{array}$ & $6 \cdot 25 \pm 0 \cdot 15$ & $0 \ddagger$ & $2.46 \pm 0.15 \ddagger$ & $3.88 \pm 0.73 \ddagger$ & $5 \cdot 25+0.55 \dagger$ & $5 \cdot 90 \pm 0 \cdot 17$ \\
\hline $\begin{array}{l}\text { Diam. of tubules } \\
\text { (um) }\end{array}$ & $316.8 \pm 4.9$ & $379 \cdot 0 \pm 3 \cdot 1 \neq$ & $360 \cdot 5 \pm 5 \cdot 3 \ddagger$ & $357.6 \pm 3.0 \dagger$ & $337.5 \pm 6.9^{*}$ & $325 \cdot 4 \pm 3 \cdot 2$ \\
\hline $\begin{array}{l}\text { Size of contraction } \\
\qquad(\mu \mathrm{m})\end{array}$ & $6.01 \pm 0.15$ & $0 \ddagger$ & $3.04 \pm 0.20 \ddagger$ & $4.42 \pm 0.26 \dagger$ & $4.92 \pm 0.25^{*}$ & $6.02 \pm 0.31$ \\
\hline
\end{tabular}

Significantly different from control values: ${ }^{*} P<0.05 ; \dagger P<0.01 ; \ddagger P<0.001$.

\section{Discussion}

The myoid cells of rat seminiferous tubules respond to PGs and other pharmacological agents much the same as do other smooth muscle-containing organs such as the gut, blood vessels and uterus in that there are changes in frequency of contractions, magnitude of contractions and changes in diameter that reflect changes in tone. In this investigation, changes in the frequency or magnitude of contractions were not the major changes induced; the changes in tone of the seminiferous tubule were much greater, i.e. of the order of $75 \mu \mathrm{m}$ as compared to 4-6 $\mu \mathrm{m}$ for changes in the magnitude of contraction.

Previous studies (Buhrley \& Ellis, 1975; Tso \& Lacy, 1975) and the present results indicate that PGs may be important as modulators of seminiferous tubular contractions. Buhrley \& Ellis (1975) established that F-type PGs could be important in the initiation of tubular contractions. When the tubules were rinsed twice in succession with fresh Tyrode's solution, the contractile frequency was diminished. Returning the original bathing medium to the tubules restored their contractile frequency, as did treatment of the rinsed tubules with PGF-1 $\alpha$. This phenomenon also occurs in the testicular capsule where extraction of the original bathing solution yielded a PG-like residue that restored contractile activity after successive changes of the bathing solution (Hargrove et al., 1973). As shown by Buhrley \& Ellis (1975) for rat tubules and Hargrove, Johnson \& Ellis (1971) for rabbit testicular capsules the effect of PGEs on the contractions of the tubules in vitro was inhibitory. Moreover, PGs are present in the testicular parenchyma and testicular capsule and their concentrations are age-dependent (Gerozissis \& Dray, 1977).

The increase in contractile responses exhibited with cGMP and the observation that cAMP 
decreases contractility (Ellis et al., 1978) suggest that both cyclic nucleotides may be important as modulators of tubular contractions. In this respect, Goldberg, Haddox, White, Lopez \& Hadden (1974) proposed the 'Yin-Yang' hypothesis of biological control since cAMP generally relaxes smooth muscle while cGMP tends to be stimulatory (Goldberg et al., 1975). Immunofluorescent techniques have shown that cAMP and cGMP stain intensely in the lamina propria of seminiferous tubules (Spruill \& Steiner, 1976; MacIndoe, Sullivan \& Wray, 1977), indicating that both cyclic nucleotides are located in the contractile tissues of the testis. The effects of $2,4^{\prime}-$ dibromoacetophenone were as expected for an inhibitor of PGF- $2 \alpha$ synthesis (Mitchell, Poyser \& Wilson, 1977). Indomethacin, also inhibits PG synthesis but 2,4'-dibromoacetophenone was more effective because it completely abolished contractions whereas indomethacin could only decrease them (Buhrley \& Ellis, 1975).

The biphasic effects of testosterone as seen in this investigation indicate two possible mechanisms of action. The higher concentration of steroid $\left(10^{-6} \mathrm{M}\right)$ is considered physiological (rat rete testis fluid and testicular venous blood contain about $160 \mathrm{nM}$ - and $316 \mathrm{~nm}$-testosterone, respectively: Free, 1977; Waites, 1977) and is required for optimal spermatogenesis. It is unlikely that rat testicular androgen concentration would normally drop much below $10^{-6} \mathrm{M}$ so the inhibitory effect of low androgen concentration would probably not occur under physiological conditions. Testosterone $\left(10^{-6} \mathrm{M}\right)$ inhibits spontaneous testicular capsular contractions in vitro (Seeley et al., 1972), but lower or higher concentrations were not tested. Bartke \& Koerner (1974) suggested that the synthesis of PGF-2 $\alpha$ in the reproductive system of the male rat is under androgenic control. Testosterone also mobilizes testicular lysosomes, thereby releasing phospholipase $\mathrm{A}_{2}$ which is rate-limiting for $\mathrm{PG}$ synthesis (Ellis, Sorenson \& Buhrley, 1975; Ellis \& Hargrove, 1977). PGs could alter androgen synthesis by changing adenyl cyclase activity, testicular blood flow, cholesterol ester synthetase or esterase activity or by acting directly on the pituitary to decrease gonadotrophin content (Ellis \& Hargrove, 1977).

An inverse relationship appears to exist for the smooth muscle of the capsule and seminiferous tubules. In those species with strong, regular capsular contractions, such as the rabbit (Davis, Langford \& Kirby, 1970), seminiferous tubular contractions are poorly developed (Ellis et al., 1978). Conversely, in the rat, no spontaneous rhythmic contractions of the capsule are seen (Davis et al., 1970; Ellis et al., 1978) but the seminiferous tubules contract actively. Since there is no innervation of the seminiferous tubules (Hargrove et al., 1977), modulation of tubule contractions by PGs could be important if such contractions are involved in sperm transport from the testis.

This work was supported by Utah State University Research, project no. U-300. We thank Dr John E. Pike, Upjohn Co., for the PGs.

\section{References}

Bartke, A. \& Koerner, S. (1974) Androgenic regulation of the concentration of prostaglandin $\mathrm{F}$ in the male reproductive system of rats and mice. Endocrinology 95, 1739-1743.

Buhrley, L.E. \& Ellis, L.C. (1975) Contractility of rat testicular seminiferous tubules in vitro: prostaglandin $\mathrm{F}_{1 a}$ and indomethacin. Prostaglandins 10, $151-162$.

Carpenter, M.P. (1974) Prostaglandins in the rat testis. Lipids 9, 397-406.

Clermont, Y. (1958) Contractile elements in the limiting membrane of the seminiferous tubules of the rat. Expl Cell Res. 15, 438-440.

Collins, P. \& Lacy, D. (1969) Studies on the structure and function of the mammalian testis. II. Cytological and histochemical observations on the testis of the rat after a single exposure of heat applied for different lengths of time. Proc. $R$. Soc, B 173, 17-26.

Davis, J.R. \& Langford, G.A. (1970) Pharmacological studies on the testicular capsule in relation to sperm transport. Adv. Exp. Med. Biol. 10, 495-514.

Davis, G.R., Lanford, G.A. \& Kirby, P.J. (1970) The testicular capsule. In The Testis, pp. 281-337. Eds A. D. Johnson, W. R. Gomes \& N. L. VanDemark. Academic Press, New York.

Ellis, L.C. (1972) Rat testicular prostaglandin synthesis and its relation to androgen synthesis. Fedn Proc. Fedn Am. Socs exp. Biol. 31, 295, Abstr.

Ellis, L.C. \& Hargrove, J.L. (1977) Prostaglandins. In The Testis, Vol. IV, pp. 289-313. Eds A. D. Johnson \& W. R. Gomes. Academic Press, New York.

Ellis, L.C., Sorenson, D.K. \& Buhrley, L.E. (1975) 
Mechanisms and interactions in testicular steroidogenesis and prostaglandin synthesis. $J$. Steroid Biochem. 6, 1081-1090.

Ellis, L.C., Buhrley, L.E. \& Hargrove, J.L. (1978) Species differences in contractility of seminiferous tubules and tunica albuginea as related to sperm transport through the testis. Arch. Androl. 1, 139146.

Firlit, C.F., King, L.R. \& Davis, J.R. (1975) Comparative response of the isolated human testicular capsule to autonomic drugs. J. Urol. 113, 500-504.

Free, M.J. (1977) Blood supply to the testis and its role in local exchange and transport of hormones. In The Testis, Vol. IV, pp. 39-90. Eds A. D. Johnson \& W. R. Gomes. Academic Press, New York.

Gerozissis, K. and Dray, F. (1977) Prostaglandins in the isolated testicular capsule of immature and young adult rats. Prostaglandins 13, 777-783.

Goldberg, N.D., Haddox, M.K., White, J.G., Lopez, C. \& Hadden, I.W. (1974) Evidence for a dualism between cyclic GMP and cyclic AMP in the regulation of cell proliferation and other cellular processes. In Cyclic AMP, Cell Growth and the Immune Response, pp. 247-262. Eds W. Braun, L. Lichtenstein \& C. Parker. Springer-Verlag, New York.

Goldberg, N.D., Haddox, M.K., Nicol, S.E., Glass, D.B., Sanford, C.H., Kuehl, F.A., Jr. \& Estensen, R. (1975) Biologic regulation through opposing influences of cyclic GMP and cyclic AMP: the yinyang hypothesis. Adv. Cyclic Nucleotide Res. 5, 307330.

Hargrove, J.L., Johnson, J.M. \& Ellis, L.C. (1971) Prostaglandin $E_{1}$-induced inhibition of rabbit testicular contractions in vitro. Proc. Soc. exp. Biol. Med. 136, 958-961.

Hargrove, J.L., Seeley, R.R. \& Ellis, L.C. (1973) Contractions of rabbit testes in vitro: permissive role of prostaglandins for the actions of calcium and some smooth muscle stimulating agents. Prostaglandins 3, $469-480$.

Hargrove, J.L., Macindoe, J.H. \& Ellis, L.C. (1977) Testicular contractile cells and sperm transport. Fert. Steril. 28, 1146-1157.

Harrison, R.G. (1953) The effect of ligation on the vasa efferentia on the rat testis. Proc. Soc. Study Fert. 5, $97-100$.

Hovatta, O. (1972) Contractility and structure of adult rat seminiferous tubules in organ culture. $Z$. Zellforsch. mikrosk. Anat. 130, 171-179.

Kormano, M. (1967) Development of the rectum-testis temperature difference in the postnatal rat. J. Reprod. Fert. 14, 427-434.

Lacy, D. (1967) The seminiferous tubule in mammals. Endeavor 26, 101-108.

Leeson, C.R. (1963) Observations on the fine structure of the rat (testis) interstitial tissue. Acta anat. 52, 3440.
Leeson, T.S. \& Cookson, R.B. (1974) The mammalian testicular capsule and its muscle elements. J. Morph. 144, 237-254.

MacIndoe, J.H., Sullivan, W. \& Wray, H.J. (1977) Immunological localization of cyclic AMP in developing rat testes. Endocrinology 101, 568-576.

Mitchell, S., Poyser, N.L. \& Wilson, N.H. (1977) Effect of $p$-bromophenacylbromide, and inhibitor of phospholipase $\mathbf{A}_{2}$, on arachidonic acid release and prostaglandin synthesis by the guinea-pig uterus in vitro. Br.J. Pharmacol. 59, 107-113.

Neter, J. \& Wasserman, W. (1974) Applied Linear Statistical Models, pp. 419-449, 473-477, 509-512. Richard D. Irwin, Inc. Homewood, Illinois, U.S.A.

Oslund, R.M. (1926) Ligation of vasa efferentia in rats. Am.J. Physiol. 77, 83-90.

Roosen-Runge, E.C. (1951) Motions of the seminiferous tubules of the rat and dog. Anat. Rec. (Suppl. 153) 109, 413, Abstr.

Ross, M.H. (1967) The fine structure and development of the peritubular contractile cell component in the seminiferous tubules of the mouse. Am.J. Anat. 121, $523-558$.

Ross, M.H. \& Long, 1.R. (1966) Contractile cells in human seminiferous tubules. Science, N.Y. 153, 1271-1273.

Seeley, R.R., Hargrove, J.L., Johnson, J.M. \& Ellis, L.C. (1972) Modulation of rabbit testicular contractions by prostaglandins, steroids and some pharmacological compounds. Prostaglandins 2, 33-40.

Smith, G. (1962) The effects of ligation on the vasa efferentia and vasectomy on testicular function in the adult rat. $J$. Endocr. 23, 385-399.

Spruill, A. \& Steiner, A. (1976) Immunohistochemical localization of cyclic nucleotides during testicular development. J. Cyclic Nucl. Res. 2, 225-239.

Suvanto, O. \& Kormano, M. (1970) The relation between in vitro contractions of the rat seminiferous tubules and the cyclic stage of the seminiferous epithelium. J. Reprod. Fert. 21, 227-232.

Tso, E.C.F. \& Lacy, D. (1975) Effects of prostaglandin $\mathrm{F}_{2 \mathrm{a}}$ on the reproductive system of the male rat. $J$. Reprod. Fert. 44, 545-550.

Urry, R.L., Asay, R.W. \& Cockett, A.T.K. (1977) Hormone control of seminiferous tubule contractions: a hypothesis of sperm transport from the testicle. Invest. Urol. 14, 194-197.

Waites, G.M.H. (1977) Fluid secretion In The Testis, Vol. IV, pp. 91-123. Eds A. D. Johnson \& W. R. Gomes. Academic Press, New York.

Wincet, H. (1977) Can cilia alone propel gametes in the oviductal isthmus and the testicular ductuli efferentes? Fedn Proc. Fedn Am. Socs exp. Biol. 36, 372.

Zawisch-Ossenitz, C. (1933) Der Flimmerstrom in den Ductuli efferentes des Hodens und die Bewegung der Spermein. Z. mikrosk. Anat. Forsch. 32, 84-106.

Received 19 February 1979 